\title{
Determination of diffusion coefficients of various livestock antibiotics in water at infinite dilution
}

\author{
Allan N. Soriano ${ }^{1, *}$, Kristoni G. Adamos ${ }^{1}$, Pauline B. Bonifacio ${ }^{1}$ Adonis P. Adornado ${ }^{1}$,Vergel C. Bungay ${ }^{1}$ and \\ Rajendaran Vairavan ${ }^{2}$ \\ ${ }^{1}$ School of Chemical Engineering and Chemistry, Mapúa University 658 Muralla St., Intramuros, Manila 1002, Philippines \\ ${ }^{2}$ School of Microelectronic Engineering, University Malaysia Perlis (UniMAP), Kampus Alam, Pauh Putra, 02600 Arau, Perlis, \\ Malaysia.
}

\begin{abstract}
The fate of antibiotics entering the environment raised concerns on the possible effect of antimicrobial resistance bacteria. Prediction of the fate and transport of these particles are needed to be determined, significantly the diffusion coefficient of antibiotic in water at infinite dilution. A systematic determination of diffusion coefficient of antibiotic in water at infinite dilution of five different kinds of livestock antibiotics namely: Amtyl, Ciprotyl, Doxylak Forte, Trisullak, and Vetracin Gold in the 293.15 to $313.15 \mathrm{~K}$ temperature range are reported through the use of the method involving the electrolytic conductivity measurements. A continuous stirred tank reactor is utilized to measure the electrolytic conductivities of the considered systems. These conductivities are correlated by using the Nernst-Haskell equation to determine the infinite dilution diffusion coefficient. Determined diffusion coefficients are based on the assumption that in dilute solution, these antibiotics behave as strong electrolyte from which $\mathrm{H}^{+}$cation dissociate from the antibiotic's anion.
\end{abstract}

\section{Introduction}

The fate of antibiotics entering the environment has many concerns regarding on its possible effects on the disturbance of the natural bacterial ecosystem. The presence of antibiotics in municipal sewage and aquatic environment are able to spread to the microbial communities. This will then result to the development of antibiotic-resistant bacteria, which can lead to a serious threat to human health. Not only does antibiotic resistance threaten the effective prevention and treatment of bacterial infectious disease but it could also make the medical procedures very dangerous to perform. However, limited information, which gives significant data for the detection and remediation of antibiotic in aquatic environment, is available to evaluate the transport properties of antibiotics. Therefore, it is important to know the fate and transport of antibiotics released in the environment to be able to properly evaluate the risks, the effects and the potential impacts of these products [1]. Fate and transport of particles is an important matter, which is concerned with the ground water, wastewater, atmosphere and soil transport of different hazardous contaminants and Pharmaceutically Active Compounds (PHAC) that describe their physical form and behavior in different media. Its primary concern is to determine the transport speed and combined effects of the chemicals in their discharge environments [2]. In order to predict the fate and transport in the environment, physicochemical properties of different substances are taken into account. There are several parameters considered such as molecular weight, aqueous solubility, chemical concentration, diffusion coefficient, Henry's law constant, boiling point and vapor pressure [3]. The study mainly focuses on the determination of diffusion coefficient of antibiotics, which can be helpful for future studies in detecting and removing antibiotics in wastewater. Diffusion coefficient indicates how individual molecules and ions move through a medium under a concentration gradient at a certain pressure and temperature. It often controls the source of a contaminant (antibiotic) released to the environment and flow usually becomes its main transport process. The diffusion coefficient can also be utilized in many remediation processes such as adsorption or chemical filtering as well as a ratedetermining step for extraction and distillation [4]. There are several methods in determining the diffusion coefficient of antibiotics in water such as diaphragm cell, interferometry, Taylor's dispersion analysis (TDA), electric conductivity, group contribution, and liquid diffusion coefficient apparatus. The most convenient way is by using electric conductivity, because it is the simplest, less expensive, rapid and clean when it comes to detection of emerging environmental pollutants. Electrolytic conductivity measures the transport of ionic substances with equivalent conductance over a homogenous solution between two electrodes [5].

In the present work, the diffusion coefficient in water at infinite dilution of the common livestock antibiotics

\footnotetext{
*Corresponding author: ansoriano@mapua.edu.ph
} 
which is rampantly used in the Philippines was indirectly determined using electrolytic conductivity data. NernstHaskell equation was then used to estimate the diffusion coefficient in water at infinite dilution of the considered system.

\section{Methodology}

The conceptual framework shown in Figure 1 shows the methodology in determining the diffusion coefficient of antibiotics in water through measurements of electrolytic conductivity using the Continuous Stirred Tank Reactor (CSTR) and correlation using the Nernst-Haskell equation. In the succeeding section, only the brief discussions of the conductivity measurements and diffusion coefficient determination was presented.

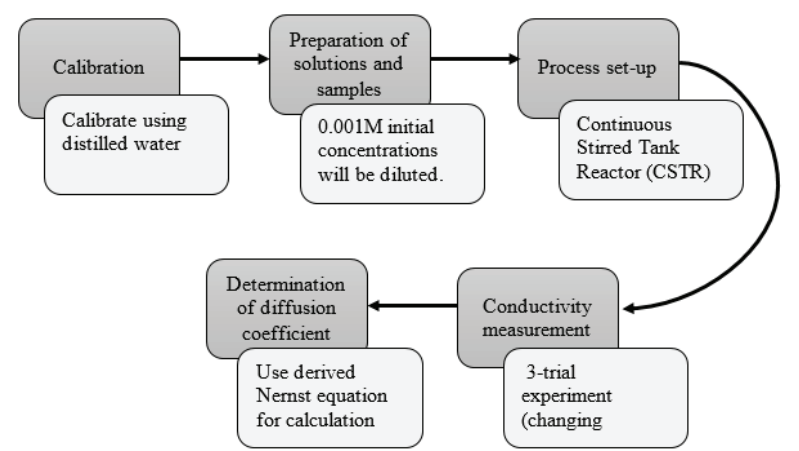

Fig. 1. Conceptual framework of the methodology applied in this work.

\subsection{Electrolytic Conductivity Measurements}

The over-all process flow diagram using the Armfield CEX Chemical Reactors Teaching Equipment, which summarizes the experimental procedure considered was presented in Figure 2. In this study only the tank reactor and hot water circulator was utilized. A one liter of distilled water was poured into the tank reactor and a small volume of aqueous solution of antibiotic, from the prepared mother solution, was introduced into the system to step up the concentration gradient. The conductivity data was collected as the temperature of the reactor increases from 293.15 to $313.15 \mathrm{~K}$ that was controlled by the hot water circulator. The recorded data was sent through the computer and the data logger where the data output port has to be connected, or simply through the direct reading from the conductivity meter in the console. Measurements were done using the desired temperatures and concentrations in three independent replicate runs for each of the five antibiotics namely: Amtyl, Ciprotyl, Doxylak Forte, Trisullak, and Vetracin Gold. The calculated volume of a known concentrated aqueous antibiotic solution was poured into the reactor to increase the concentration from $0.0002 \mathrm{M}$ to $0.0014 \mathrm{M}$. The heater installed in the equipment was operated using a demineralized water and must reach the water level of $30 \mathrm{~mm}$ from the top of the vessel. The temperature adjustment was done and controlled through the PID controller software installed in the computer.

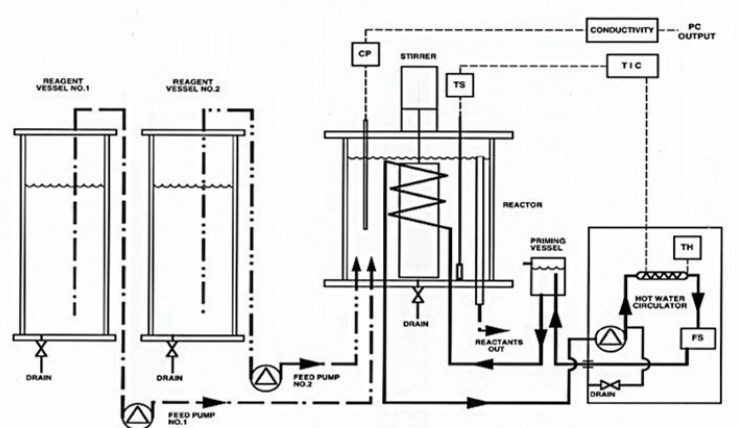

Fig. 2. Process flow diagram of the measurement of electrolytic conductivity

\subsection{Diffusion Coefficient Determination}

Using the Nernst-Haskell equation, as in Eqn. (1), the diffusion coefficient of the considered systems in water at infinite dilution was evaluated [7].

$$
D_{A B}^{0}=\frac{R T}{F^{2}} \frac{\left|z_{+}\right|+|| z_{-} \mid}{|z, z|} \frac{\Lambda_{+}^{0} \Lambda_{-}^{0}}{\Lambda_{+}^{0}+\Lambda_{-}^{0}}
$$

where $D_{A B}^{0}$ is denoted as the diffusion coefficient of the solute, which is the antibiotic (A) in water (B) at infinite dilution in $\mathrm{m}^{2} / \mathrm{s}, R$ is the universal gas constant in $\mathrm{J} / \mathrm{mol}$ $\mathrm{K}, T$ is the absolute temperature in $\mathrm{K}$ and $F$ is the Faraday's constant. The $\mathrm{z}_{+}$and $\mathrm{z}_{-}$designate the charge number of the cation and anion, respectively, and $\Lambda_{+}^{0}$ and $\Lambda_{-}^{0}$ are the molar conductivities of the cation and anion in $\mathrm{Sm}^{2} / \mathrm{mol}$, respectively at infinite dilution.

The molar conductivity was determined using the measured electrolytic conductivity, $\kappa \mathrm{K}$, in $\mathrm{S} / \mathrm{m}$, which depends primarily on the type of electrolyte and the molar concentration of the solution in $\mathrm{kmol} / \mathrm{m}^{3}$. Equation (2) shows the given formula for the evaluation of molar conductivity, $\Lambda$, in $\mathrm{S} \cdot \mathrm{m}^{2} / \mathrm{mol}$ [8]

$$
\Lambda=\left(\frac{\kappa}{C \cdot 1000}\right)
$$

The molar conductivities of the cation and anion at infinite dilution are determined using the Kohlrausch's law of the Independent Migration of Ions which states that the molar conductivity of an electrolyte at infinite dilution can be expressed in terms of the sum of contribution from the cation and anion of antibiotic in dilute solution as presented in Eqn. (3) [8]

$$
\Lambda^{0}=z_{+} \Lambda_{+}^{0}+z_{-} \Lambda_{-}^{0}
$$

The molar conductivity at infinite dilution, $\Lambda^{0}$, is determined using the modified form of the Robinson and Stokes equation and is presented as Eqn. (4) [9].

$$
\Lambda=\Lambda^{0}+a_{1} C^{1 / 2}+a_{2} C
$$




\section{Results and Discussion}

\subsection{Electrolytic Conductivity Data}

The measured electrolytic conductivity data for different concentrations $(0.0002$ to $0.0014 \mathrm{M})$ of the considered antibiotics at various temperature (293.15 to $313.15 \mathrm{~K}$ ) are presented in Table 1.

Table 1. Measured electrolytic conductivities, $\kappa$, of antibiotics at different concentrations and temperatures.

\begin{tabular}{|c|c|c|c|c|c|}
\hline \multicolumn{6}{|c|}{ Amtyl (amoxicillin + tylosin): $\left[\mathrm{H}^{+}\right]\left[\mathrm{AMT}^{-}\right]^{*}$} \\
\hline $\begin{array}{c}C / \\
(\mathrm{kmol} \\
\left.\mathrm{m}^{-3}\right)\end{array}$ & 0.0002 & 0.0005 & 0.0008 & 0.0011 & 0.0014 \\
\hline$T / \mathrm{K}$ & \multicolumn{5}{|c|}{$\kappa / \mathrm{mS} \cdot \mathrm{cm}^{-1}$} \\
\hline 293.15 & 0.1933 & 0.2463 & 0.2944 & 0.3392 & 0.3857 \\
\hline 298.15 & $\begin{array}{c}0.2151 \\
35\end{array}$ & $\begin{array}{c}0.2730 \\
31\end{array}$ & $\begin{array}{c}0.3284 \\
8\end{array}$ & $\begin{array}{c}0.3798 \\
53\end{array}$ & $\begin{array}{c}0.4247 \\
01\end{array}$ \\
\hline 303.15 & $\begin{array}{c}0.2337 \\
90\end{array}$ & $\begin{array}{c}0.3006 \\
56\end{array}$ & $\begin{array}{c}0.3577 \\
36\end{array}$ & $\begin{array}{c}0.4172 \\
63\end{array}$ & $\begin{array}{c}0.4751 \\
59\end{array}$ \\
\hline 308.15 & $\begin{array}{c}0.2548 \\
91 \\
\end{array}$ & $\begin{array}{c}0.3266 \\
49\end{array}$ & $\begin{array}{c}0.3943 \\
30 \\
\end{array}$ & $\begin{array}{c}0.4579 \\
34\end{array}$ & $\begin{array}{c}0.5125 \\
68\end{array}$ \\
\hline 313.15 & $\begin{array}{c}0.2750 \\
78\end{array}$ & $\begin{array}{c}0.3541 \\
75\end{array}$ & $\begin{array}{c}0.4291 \\
94\end{array}$ & $\begin{array}{c}0.4976 \\
91\end{array}$ & $\begin{array}{c}0.5670 \\
03\end{array}$ \\
\hline \multicolumn{6}{|c|}{ Ciprotyl (ciprofloxacin): $\left[\mathrm{H}^{+}\right]\left[\mathrm{CIP}^{-}\right]$} \\
\hline $\begin{array}{c}C / \\
\left(\mathrm{kmol}^{-}\right. \\
\left.\mathrm{m}^{-3}\right)\end{array}$ & 0.0002 & 0.0005 & 0.0008 & 0.0011 & 0.0014 \\
\hline$T / \mathrm{K}$ & \multicolumn{5}{|c|}{$\kappa / \mathrm{mS} \cdot \mathrm{cm}^{-1}$} \\
\hline 293.15 & $\begin{array}{c}0.1802 \\
72\end{array}$ & $\begin{array}{c}0.2218 \\
59\end{array}$ & $\begin{array}{c}0.2585 \\
53\end{array}$ & $\begin{array}{c}0.3001 \\
4\end{array}$ & $\begin{array}{c}0.3360 \\
19\end{array}$ \\
\hline 298.15 & $\begin{array}{c}0.2004 \\
57\end{array}$ & $\begin{array}{c}0.2444 \\
91\end{array}$ & $\begin{array}{c}0.2844 \\
47\end{array}$ & $\begin{array}{c}0.3358 \\
19\end{array}$ & $\begin{array}{c}0.3765 \\
91\end{array}$ \\
\hline 303.15 & $\begin{array}{c}0.2174 \\
82\end{array}$ & $\begin{array}{c}0.2688 \\
54\end{array}$ & $\begin{array}{c}0.3161 \\
49\end{array}$ & $\begin{array}{c}0.3667 \\
06\end{array}$ & $\begin{array}{c}0.4115 \\
55\end{array}$ \\
\hline 308.15 & $\begin{array}{c}0.2369 \\
52\end{array}$ & $\begin{array}{c}0.2899 \\
55\end{array}$ & $\begin{array}{c}0.3462 \\
20\end{array}$ & $\begin{array}{c}0.3975 \\
92\end{array}$ & $\begin{array}{c}0.4522 \\
26\end{array}$ \\
\hline 313.15 & $\begin{array}{c}0.2579 \\
53\end{array}$ & $\begin{array}{c}0.3134 \\
03\end{array}$ & $\begin{array}{c}0.3770 \\
07\end{array}$ & $\begin{array}{c}0.4340 \\
87\end{array}$ & $\begin{array}{c}0.4944 \\
29\end{array}$ \\
\hline \multicolumn{6}{|c|}{$\begin{array}{l}\text { Doxylak Forte (doxycyline tiamulin hydrogen } \\
\text { fumarate): }\left[\mathrm{H}^{+}\right]\left[\mathrm{DOX}^{-}\right]\end{array}$} \\
\hline $\begin{array}{c}C / \\
(\mathrm{kmol} \cdot \\
\left.\mathrm{m}^{-3}\right)\end{array}$ & 0.0002 & 0.0005 & 0.0008 & 0.0011 & 0.0014 \\
\hline$T / \mathrm{K}$ & \multicolumn{5}{|c|}{$\kappa / \mathrm{mS} \cdot \mathrm{cm}^{-1}$} \\
\hline 293.15 & $\begin{array}{c}0.2153 \\
35\end{array}$ & $\begin{array}{c}0.2879 \\
09\end{array}$ & $\begin{array}{c}0.3458 \\
05\end{array}$ & $\begin{array}{c}0.3996 \\
23\end{array}$ & $\begin{array}{c}0.4469 \\
18\end{array}$ \\
\hline 298.15 & $\begin{array}{c}0.2371 \\
52 \\
\end{array}$ & $\begin{array}{c}0.3162 \\
49 \\
\end{array}$ & $\begin{array}{c}0.3798 \\
53 \\
\end{array}$ & $\begin{array}{c}0.4385 \\
64 \\
\end{array}$ & $\begin{array}{c}0.4940 \\
13 \\
\end{array}$ \\
\hline 303.15 & $\begin{array}{c}0.2574 \\
38\end{array}$ & $\begin{array}{c}0.3406 \\
12\end{array}$ & $\begin{array}{c}0.4115 \\
55\end{array}$ & $\begin{array}{c}0.4767 \\
89\end{array}$ & $\begin{array}{c}0.5306 \\
08\end{array}$ \\
\hline 308.15 & $\begin{array}{c}0.2769 \\
08\end{array}$ & $\begin{array}{c}0.3690 \\
52\end{array}$ & $\begin{array}{c}0.4465 \\
18\end{array}$ & $\begin{array}{c}0.5125 \\
68\end{array}$ & $\begin{array}{c}0.5794 \\
34\end{array}$ \\
\hline 313.15 & $\begin{array}{c}0.2987 \\
25\end{array}$ & $\begin{array}{c}0.3949 \\
46\end{array}$ & $\begin{array}{c}0.4797 \\
51\end{array}$ & $\begin{array}{c}0.5555 \\
86\end{array}$ & $\begin{array}{c}0.6191 \\
90\end{array}$ \\
\hline \multicolumn{6}{|c|}{ Trisullak (contramazine): $\left[\mathrm{H}^{+}\right]\left[\mathrm{TRI}^{-}\right]$} \\
\hline $\begin{array}{c}C / \\
(\mathrm{kmol} \\
\left.\mathrm{m}^{-3}\right)\end{array}$ & 0.0002 & 0.0005 & 0.0008 & 0.0011 & 0.0014 \\
\hline$T / \mathrm{K}$ & \multicolumn{5}{|c|}{$\kappa / \mathrm{mS} \cdot \mathrm{cm}^{-1}$} \\
\hline 293.15 & $\begin{array}{c}0.1770 \\
10\end{array}$ & $\begin{array}{c}0.2116 \\
95\end{array}$ & $\begin{array}{c}0.2477 \\
88\end{array}$ & $\begin{array}{c}0.2838 \\
11\end{array}$ & $\begin{array}{c}0.3156 \\
34\end{array}$ \\
\hline 298.15 & 0.1963 & 0.2368 & 0.2737 & 0.3154 & 0.3545 \\
\hline
\end{tabular}

\begin{tabular}{|c|c|c|c|c|c|}
\hline & 80 & 44 & 54 & 84 & 74 \\
\hline 303.15 & $\begin{array}{c}0.2134 \\
05\end{array}$ & $\begin{array}{c}0.2571 \\
30\end{array}$ & $\begin{array}{c}0.3005 \\
63\end{array}$ & $\begin{array}{c}0.3448 \\
11\end{array}$ & $\begin{array}{c}0.3879 \\
07\end{array}$ \\
\hline 308.15 & $\begin{array}{c}0.2328 \\
75\end{array}$ & $\begin{array}{c}0.2815 \\
65\end{array}$ & $\begin{array}{c}0.3298 \\
90\end{array}$ & $\begin{array}{c}0.3757 \\
69\end{array}$ & $\begin{array}{c}0.4245 \\
01\end{array}$ \\
\hline 313.15 & $\begin{array}{c}0.2514 \\
30\end{array}$ & $\begin{array}{c}0.3041 \\
97\end{array}$ & $\begin{array}{c}0.3591 \\
18\end{array}$ & $\begin{array}{c}0.4107 \\
76\end{array}$ & $\begin{array}{c}0.4626 \\
27\end{array}$ \\
\hline $\left.\begin{array}{c}\text { Vetracin Gold (doxycycline tiamulin vitamin A+B12): } \\
{\left[\mathrm{H}^{+}\right][\mathrm{VET}}\end{array}\right]$ \\
\hline $\begin{array}{c}C / \\
\left(\mathrm{kmol}^{-} \cdot\right. \\
\left.\mathrm{m}^{-3}\right)\end{array}$ & 0.0002 & 0.0005 & 0.0008 & 0.0011 & 0.0014 \\
\hline$T / \mathrm{K}$ & \multicolumn{5}{|c|}{$\kappa / \mathrm{mS} \cdot \mathrm{cm}^{-1}$} \\
\hline 293.15 & $\begin{array}{c}0.2047 \\
35\end{array}$ & $\begin{array}{c}0.2724 \\
16\end{array}$ & $\begin{array}{c}0.3596 \\
67\end{array}$ & $\begin{array}{c}0.4509 \\
96\end{array}$ & $\begin{array}{c}0.5358 \\
01\end{array}$ \\
\hline 298.15 & $\begin{array}{c}0.2257 \\
36\end{array}$ & $\begin{array}{c}0.2999 \\
4\end{array}$ & $\begin{array}{c}0.3969 \\
77\end{array}$ & $\begin{array}{c}0.4931 \\
98\end{array}$ & $\begin{array}{c}0.6032 \\
81\end{array}$ \\
\hline 303.15 & $\begin{array}{c}0.2443 \\
91\end{array}$ & $\begin{array}{c}0.3267 \\
5\end{array}$ & $\begin{array}{c}0.4360 \\
18\end{array}$ & $\begin{array}{c}0.5306 \\
08\end{array}$ & $\begin{array}{c}0.6553 \\
69\end{array}$ \\
\hline 308.15 & $\begin{array}{c}0.2646 \\
77\end{array}$ & $\begin{array}{c}0.3527 \\
43\end{array}$ & $\begin{array}{c}0.4677 \\
19\end{array}$ & $\begin{array}{c}0.5818 \\
80\end{array}$ & $\begin{array}{c}0.7041 \\
95\end{array}$ \\
\hline 313.15 & $\begin{array}{c}0.2856 \\
78\end{array}$ & $\begin{array}{c}0.3802 \\
68\end{array}$ & $\begin{array}{c}0.5082 \\
91\end{array}$ & $\begin{array}{c}0.6224 \\
52\end{array}$ & $\begin{array}{c}0.7602 \\
60\end{array}$ \\
\hline
\end{tabular}

*Assumed ions comprising the antibiotics.

The conductivity of all solution changes as the temperature changes. Based from the graph, the relationship between the two parameters is as the temperature increases the electrolytic conductivity increases as well. Therefore, this trend line indicates a linear relationship between the two parameters which can be seen in all systems of antibiotics tested in this study. This relationship can be associated with the interionic attractions of the given solution. An increase in temperature can cause the number of ions to increase because of dissociation of molecules which is a factor that affects the electrolytic conductivity of a solution [6]. Therefore, as the conductivity is affected by this factors, then an increase in a system's temperature will lead to an increase in the electrolytic conductivity. Figure 3 shows the calculated values of molar conductivity of the studied systems as function of concentration and temperature. The behavior of the molar conductivity as a function of concentration can be observed to be decreasing exponentially at lower concentration and seems to becoming linear as the concentration increases. As the concentration of ions increases, the interionic attractions also increases. These interactions affect the conductivity of an electrolytic solutions because these interionic attractions can reduce the capability of ions in an electrolytic solution to conduct the electric current between the electrodes [6]. Higher concentrations will hinder the motion of ions which results to a decrease in the conductance. At lower concentration or at more dilute solutions, the ions are far apart which decreases the interionic attractions and increase the dissociation of ions and at the same time increases the molar conductivity. Ions become unaffected by each other's motion which causes them to migrate independently as was proven by Kohlrausch's principle. 

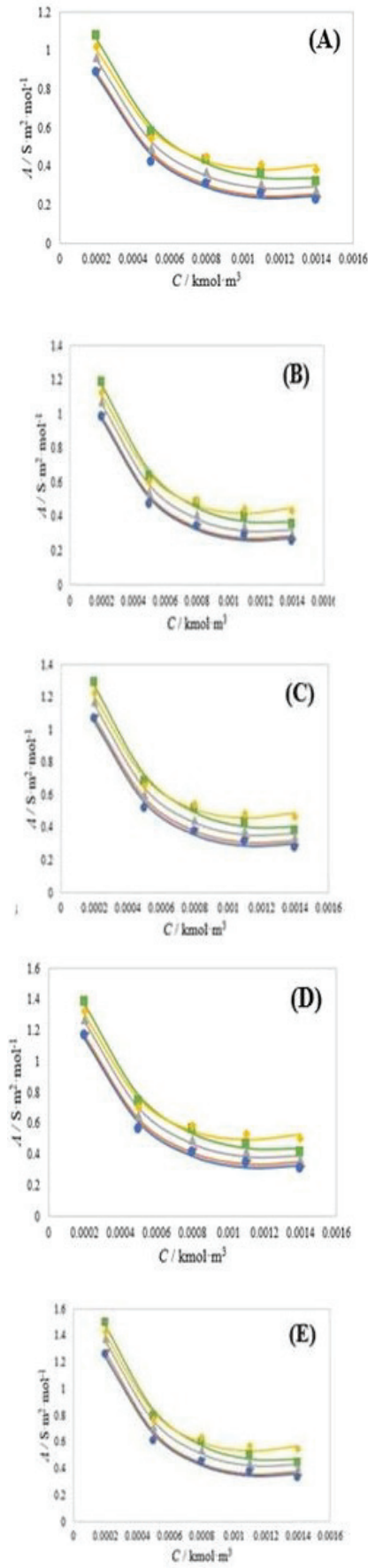

Fig. 3. Molar conductivity of the studied systems as function of concentration and temperature (A. $T=293.15 \mathrm{~K}$; B. $T=$ $298.15 \mathrm{~K}$; C. $T=303.15 \mathrm{~K}$; D. $T=308.15 \mathrm{~K}$; E. $T=313.15 \mathrm{~K}$ ): (॰, Trisullak; -, Vetracin Gold; $\Delta$, Amtyl; , Doxylak Forte; - Ciprotyl), and lines are calculated values using Eqn. (4).

\subsection{Determined Diffusion Coefficient at Infinite Dilution}

There are few studies which focus on the diffusion of antibiotics in water. In this study, the conductivities of antibiotic solutions were determined at an infinite dilution state. It was assumed and estimated that the antibiotics have strong electrolyte ions in which $\mathrm{H}^{+}$ cations dissociate from the $\mathrm{CIP}^{1-}, \mathrm{TRI}^{1-}, \mathrm{AMT}^{1-}, \mathrm{VET}^{1-}$, and $\mathrm{DOX}^{1-}$ anions. The diffusion coefficient at infinite dilution of the considered systems was estimated using the Nernst-Haskell equation given in Eqn. (1). The Nernst-Haskell equation is used for diffusion of electrolytes which dissociate into ions of unequal valence similar to the system. The infinite dilution diffusion coefficient calculated using the Nernst-Haskell equation is given in Table 2 and is representatively shown in the plot against the absolute temperatures as shown in Figure 4, where it was found that an increase in temperature causes an increase in diffusion coefficient due to the increasing mobility of ions.

Table 2. Determined diffusion coefficient at infinite dilution, $D_{A B}^{0}$, of the studied antibiotics in water.

\begin{tabular}{|c|c|c|c|c|c|}
\hline & \multicolumn{5}{|c|}{$10^{7} D^{o}{ }_{A B} / \mathrm{m}^{2} \cdot \mathrm{s}$ (Nernst-Haskell eqn.) } \\
\hline$T / \mathrm{K}$ & Amtyl & Ciprotyl & $\begin{array}{c}\text { Doxylak } \\
\text { Forte }\end{array}$ & Trisullak & $\begin{array}{c}\text { Vetracin } \\
\text { Gold }\end{array}$ \\
\hline 293.15 & 0.084332 & 0.084269 & 0.084422 & 0.084261 & 0.084373 \\
\hline 298.15 & 0.091660 & 0.091598 & 0.091751 & 0.091585 & 0.091699 \\
\hline 303.15 & 0.099377 & 0.099316 & 0.099469 & 0.099299 & 0.099414 \\
\hline 308.15 & 0.107490 & 0.107431 & 0.107582 & 0.107408 & 0.107525 \\
\hline 313.15 & 0.116004 & 0.115947 & 0.116095 & 0.115918 & 0.116037 \\
\hline
\end{tabular}

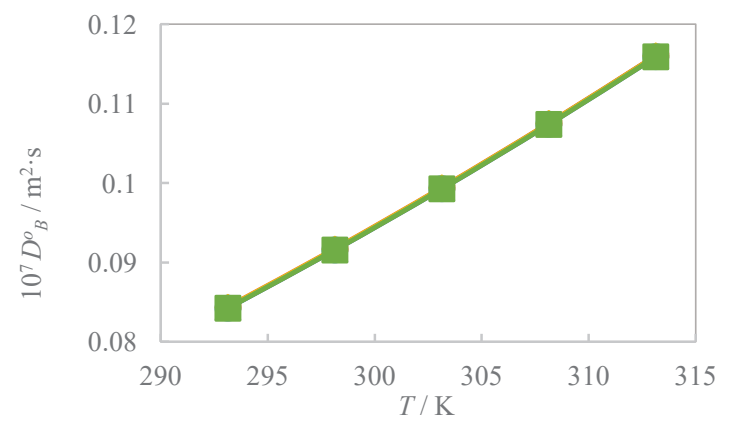

Fig. 4. Infinite dilution diffusion coefficient of Trisullak in water as function of temperature

\section{Conclusion}

This study mainly focuses on the estimation of diffusion coefficient of antibiotics in water at infinite dilution through the use of electrolytic conductivity method. The measurable data obtained from the experiment is correlated using the models and correlations available. The Nernst-Haskell equation was utilized for the determination of infinite dilution diffusion coefficient. The study was conducted at different temperatures to further investigate the different conditions of antibiotic when present in the aquatic environment

\section{References}

1. P. Segura, A. Garcia-Ac, A. Lajeunesse, D. Ghosh, C. Gagnon, and S. Sébastien, J. Environ. Monitoring, vol. 9, pp. 307-313, (2007).

2. J. G. Sczechowski, ENVE 436: Fate and Transport. Retrieved 1, February 2016, Available: 
http://ceenve3.civeng.calpoly.edu/cota/enve436/fate. html, (1997).

3. Bester-Rogac, M., Boncina, M., Apelblat, Y., and Apelblat, A., Journal of Physical Chemistry, 111. 11957-11967, (2007). .

4. Soriano, A.N., Entrolizo, R.V., Era, C.M.A., San Diego, J.S.H., Li, M.-H., PIChE Journal, 15, 54-63, (2014).

5. L. van der Wielen, M. Zomerdijk, J. Houwers, K. Luyben, Chem. Eng. J., vol. 66, pp. 111-121, (1997).

6. Apelblat, A. and Bester-Rogac, M., Journal of Molecular Liquids, 421, (2015).

7. F. Fiegenbaum, G. Peres, M. O. de Souza, E. M. A. Martini, and R. F. de Souza, J. Mol. Liq., vol. 215, pp. 302-307, (2016).

8. S. Thawarkar, N. D. Khupse, and A. Kumar, Phys. Chem. Chem. Phys., vol. 17, no. 1, pp. 475-482, (2015).

9. J. T. Edward, J. chem. Educ, vol. 47, no. 4, p. 261, (1970). 